Wilfrid Laurier University

Scholars Commons @ Laurier

Spring 2006

\title{
The Predicament of Nature: Keiko the Whale and The Cultural Politics of Whaling in Iceland
}

Anne Brydon

Wilfrid Laurier University, abrydon@wlu.ca

Follow this and additional works at: https://scholars.wlu.ca/anth_faculty

\section{Recommended Citation}

Brydon, Anne, "The Predicament of Nature: Keiko the Whale and The Cultural Politics of Whaling in Iceland" (2006). Anthropology Faculty Publications. 2.

https://scholars.wlu.ca/anth_faculty/2

This Article is brought to you for free and open access by the Anthropology at Scholars Commons @ Laurier. It has been accepted for inclusion in Anthropology Faculty Publications by an authorized administrator of Scholars Commons@Laurier. For more information, please contact scholarscommons@wlu.ca. 


\title{
The Predicament of Nature: Keiko the Whale and The Cultural Politics of Whaling in Iceland
}

\author{
Anne Brydon \\ Wilfrid Laurier University
}

\begin{abstract}
This cultural analysis reconsiders the modernist narrative about the politics of whales and whale hunting in order to explore Icelandic responses to the return of the killer whale Keiko (star of the Free Willy movies) to Icelandic waters in 1998. Ambivalence about Keiko's plight required cultural creativity to block identification with the whale since in Icelandic hegemonic discourse such feelings have been associated with the supposed irrationality of foreign protests against whale hunting. This essay draws on Bruno Latour's writings about the politics of nature to argue for abandoning nature in a step toward the ethnographic study of human-nonhuman relations. [Keywords: cultural critique, nature, modernity, Iceland, whales and whaling]
\end{abstract}


A whaling nation that didn't hunt whales much and a whale that could not be killed: when on 10 September 1998 Keiko the killer whale returned ${ }^{1}$ from Oregon to his home waters around Iceland aboard a United States military Boeing C-17 aircraft, twenty years had passed since Greenpeace protestors first tried but failed to intervene between the harpoon of an Icelandic whaling boat and a whale held in its sights. At either end of those twenty years, the figure of the whale embodied different but always multivalent meanings, tracing a shift-or so it would seem-from initial fear and anger, to indignation, then to ambivalence mixed with cynicism.

Keiko became famous as the captured whale portrayed in three internationally-popular Free Willy movies $(1993,1995,1997)$ released by Time Warner, the American-based global media giant. His near-death in a Mexican aquarium and subsequent rescue to an aquarium in Oregon developed into a localised and focused expression of identity in the moves to return him to the Icelandic waters from which he had been taken by an Icelandic whale-broker in 1979. While he lived in Iceland, Keiko was used by the conservation group Ocean Futures (headed by Jean-Michel Cousteau and responsible for Keiko's care and training) to represent in text and image what its American board of directors defined as appropriate relations to nature. The Humane Society of the United States took over his care in 2002, and that summer they released Keiko with the hope he would join a local killer whale pod. Instead, Keiko meandered the North Atlantic until he encountered a Norwegian fishing boat. He followed it into a fjord to where Norwegian families subsequently flocked to visit the famous whale. His American caregivers set up in that country and continued their efforts to backtrain him for release in the wild. Keiko died of pneumonia in December 2003.

This paper looks at Icelandic responses to Keiko's local sojourn from 1998 to 2002 within the context of the on-going cultural politics of whales and whale hunting. It contributes to an anthropology of reason by examining how contemporary Icelanders' emotional ambivalence associated with whales in general and Keiko in particular has contributed to a reactive nationalist identification with a self-image of rationality. Corollary to this study of Keiko's impact is an examination of the binary distinction drawn between reason and emotion found in the rhetoric associated with the cultural politics of whales and whaling. This distinction figures in arguments put forward by Icelandic and international pro-whaling forces to justify their own stance against the alleged sentimentality and greed of international anti-whaling forces. However, over the last decade, the weakened national solidarity behind the 
pro-whaling position in Iceland as whale-watching tourism proved successful has opened up the figure of the whale to multiple negotiations over its meaning (although this has not meant increasing support for an anti-whaling position). These negotiations have in turn raised for ethnographic analysis the role played by non-human sentient nature in moral reasoning about emotional maturity, property relations, media consumption, and national identity.

Focussing on how reason and rationality are used as identity markers within transnational environmental debates raises intriguing questions about the status of scientific knowledge, particularly in ethnographic accounts, and the modernist separation of nature from politics. To this end, this paper contributes to the anthropology of modernity and modernities by drawing upon science studies in order to relativize the modernist assumption that non-social nature exists, and that science provides direct, unmediated access to it.

The hegemonic belief in the West about its own modernity depends on the assumption that nature exists separate from culture. The ambiguity of the term "nature" (Icelandic: náttúra) has been highly productive for thought and its shifting but relatively stable meanings are central to ideas about human identity and collectivity, justice, knowledge, and history. While this centrality posits nature as the ground or guarantor of truth, it also produces a gap in which anxiety proliferates. As Slavoj Zizek comments (1991), human relationships with what is called nature are premised in fear, power, force, and dependence. Thus, while the concept of nature provides a foil for abstract thought, it is also something with which, through symbolic processes attributing the source of anxiety to something embodied and identifiable, people have fraught, corporeal dealings. In the politics of whales and whaling, the source of anxiety, depending on one's position within the issue, is imagined to lie in the demonized figures of the whale (i.e., viewed as a competitor for fish), the whaler, or the environmentalist.

The anthropology of modernity/modernities has largely, but not entirely, been concerned with the extension and localization of hegemonic European modernist concepts and institutions in the non-West (e.g. Comaroff and Comaroff 1993, Ferguson 1999, Ivy 1995, Mintz 1985, Mitchell 2000, Rofel 1999). Nonetheless, the interpretation of events and situations within a temporalized framework that separates facts from values, Science from Society, the world from its representations, and rationality from irrationality-an interpretation which assumes the reality of modernity-is far from stable and all-pervasive within Europe, much less without (cf. Serematakis 1994). While critical traditions within European scholarship have long critiqued the posi- 
tive valuation of modernity and shown instead its darker attributes, questioning the ontological status of modernity itself is a more recent phenomenon.

An anthropology of modernity that refracts the study of other modernities back onto Europe can contribute to the project of decolonizing eurocentric thought. However, in order not to just stop there-in this case, documenting yet another cultural understanding of nature without dismantling "nature" itself-this paper considers the cultural politics of the whaling issue from the perspective set forth by Bruno Latour in his pathbreaking We Have Never Been Modern (1993) and more recent Politics of Nature (2004). In these works, Latour brings comparative anthropology together with political ecology and science studies to propose an alternative conceptual context. In brief, Latour critiques what he calls the "modern constitution": the ideological effort of modern thought to keep separate the realm of nature (the discursive space of science) and the realm of culture (the discursive space of politics) despite their continual hybridization in practice. As he notes, modernist thought has promised unmediated access to nature by means of scientific knowledge, even though in the actual practices of science one cannot escape representation and its consequences. In place of the modern constitution he proposes a move away from the institutions of "mononaturalism" and "multiculturalism," and a move toward "multinaturalism." Multinaturalism he posits as a collective community made up of both human and non-humans. It would draw upon the sciences as they are actually practised, by scientists who don't claim the authority of absolute reason, but rather act as diplomats within a broad-reaching extension of democracy into the sciences themselves. The non-human world would be interlocutors within this new collective, with the sciences acting as their prosthesis of speech.

Latour's proposal is particularly enticing given how the organization responsible for managing whales and whaling, the International Whaling Commission (IWC), is structured. The IWC is an instrumental means for the rationalization of nature (whales) and culture (whalers), set up by the U.S. government just after WW II. IWC protocols assume and naturalize through social practice the separation of nature and culture by placing nature in the realm of science, and culture in the realm of politics. Each member nation sends political representatives to the annual meeting, while a separate Scientific Committee provides the knowledge on which management decisions are supposed to be based. During the 1970s, when whaling moved from (using Latour's terms) a matter of fact-an industry largely governing itself by distributing kill quotas- to a matter of concern - when the figure of the whale 
constellated in the West a newly emergent environmental consciousness-the Scientific Committee became the site for contesting appropriate knowledge about whales and whaling. Member states increased the number of their scientific advisors, and different types of scientific practice entered into IWC management debates. In one instance during the late $1980 \mathrm{~s}$, at least according to one Icelandic scientist, the scientists ended up voting on a scientific result, thus exposing how politics informs knowledge production. Nonetheless, pro- and anti-whalers both claim that science supporting their political positions is value-free and they challenge only the disinterestedness of their opponents' science, and never the ability of science itself to speak with unchallenged authority about nature.

Seen in this light, claims to rationality and reason that figure in Icelandic identity have less to do with actual reason and rationality, and more to do with political discourse. In Iceland and elsewhere, "rationality" in pro-whaling discourse refers to a specific understanding of the rational as shaped in the bureaucratic structures of modernity. Nonetheless, because its use is more metaphorical than propositional, the term carries with it a burden of constellated moral assumptions. As Raymond Williams argues (1976:252), "we need only think of the contemporary distance between reasonableness and rationalization" to recognize the broad ways in which the term "rational" can mean. What Williams notes regarding rationality pertains to Icelandic reactions to foreign environmentalism, in that "...new kinds of action, which have rationales and are often supported by extensive reasoning are dismissed as irrational ...because they are not reasonable (moderate) in the conventional sense" (255). To be thought rational, then, "is to have certain assumptions of purpose, system or method which are then so deeply held that for others to challenge them is not only unreasonable but irrational (and probably a rationalization of some quite other emotion or motive)" (ibid.).

Latour's context for acknowledging the non-existence of nature provides anthropology with an alternative to providing armaments in the war of words within environmental disputes. At present, in the context of the whaling issue, anthropologists side with whalers and focus their writings on diminishing the sincerity and rationality of environmentalists involved in anti-whaling campaigns. They conceive of anti-whaling activists as removed from nature and thereby superstitious and irrational when it comes to the intelligence of whales. Arguments about whale management by totemization, or the treating of whales as "sacred cows" or "mediagenic megafauna" have been developed to this end (Einarsson 1993, 1996; Freeman 1990; Freeman and Kreuter 1994; 
Kalland 1993; Kalland and Moeran 1990). Anti-whaling activist rhetoric returns fire: whalers (pictured always with techno-giant factory ships and never small ships and wooden-hulled boats) are barbaric and indiscriminate killers who must be forced along an evolutionary path toward a more humane, civilized, and enlightened treatment of whales. Further, whales themselves, being intelligent and peaceful, are exemplary of enlightenment values, as is Nature's supposed balance and harmony when not disrupted by (morally) inappropriate human action.

What if anthropology were to abandon nature altogether? Nature has in some regards already been disappearing from the discipline's view. The 19thcentury search for the Noble Savage, the child of nature, gave way to a more ethnographically-informed recognition of the ethnocentrism of such an enterprise, one that associates the non-West with bestiality. Nonetheless, the view that natives lived more harmoniously with nature than non-natives has persisted longer, even in the face of empirical studies of disharmony, error, and ecological destruction (for example, Krech 1999). A symmetrical anthropology would acknowledge the full consequences of what we have learned: that nature and mononaturalism are modernist constructs not shared by all peoples, who more often than not don't see a gap between humans and what is referred to problematically as the biophysical world. Such a view would engage Vivieros' (2003) call for an anthropology of conceptual imagination that considers what it means to "think native thought" by taking it seriously and pursuing its consequences. Importantly, letting go of nature would also mean letting go of a view of Science that claims it can speak with authority about what is and is not rational and true. Brought back to Europe, such thinking with native thought would shed new light on the fractures within European modernity, and the attempts to think about non-humans beyond the limits of instrumental rationality.

The research on which this paper is based began in July 1988, when I travelled to Iceland to begin two years of field research on nationalism and selfidentity. I have since returned to Iceland seven times for visits ranging from four weeks to four months, and returned to the topic of the whaling issue in the late 1990s (Brydon 1990, 1992, 1996). I arrived in Iceland one week after Keiko landed, and the following year I spent ten days at the Westman Islands Research Institute near where Keiko was then confined within a floating pen sheltered in a bay. Interviews, newspaper coverage for the months leading up to and following Keiko's return, internet-based research on Keiko, whales in general, and the whaling issue, and on-going participant observation in 
Iceland provide the background for this discussion of the tropes which inform Icelandic understandings of Keiko's position in the on-going cultural politics of whales and whale hunting.

During my initial stay, I was repeatedly told by Icelanders I met that I ought to research the whaling issue since events at that time-in particular, calls for boycotts against purchase of Icelandic fish and fish products-were making them very nationalistic, despite whale hunting's lack of historical, cultural, or economic significance in their country. I was uncertain about engaging with a controversy that might oblige me to advocate on behalf of Iceland's whalers, similar to how Canadian anthropologists I had studied with advocated for Aboriginal Peoples affected by international anti-fur-trapping and anti-sealing campaigns. It was the predominant interpretive trope at the time-in fact, Icelanders likened themselves to Newfoundland and Greenlandic sealers who had lost their livelihood to anti-sealing campaigns-yet I found it difficult to accept at face value in the context of commercial whaling increasingly geared toward exporting meat to Japan. Potential anthropological arguments in defence of subsistence needs, local consumption, and/or cultural significance were undermined by the status of whale meat as a commodity within a transnational capitalist production/consumption system. The figure of the hunter that is encoded in the International Whaling Commission's (IWC) distinction between aboriginal and commercial whaling assumes that the hunter exists outside the capitalist system. The distinction between capitalist and non-capitalist production is fraught in many ways, not least because of how it is mobilized by both pro- and anti-whalers to support their respective positions and to assert what people and actions they consider closer to, or friendlier toward, the natural. Nonetheless, both sides have also criticized the IWC's aboriginal/commercial distinction, albeit to different ends, exemplifying the de facto instability of categories claimed to be unambiguous facts about the world.

\section{The Whaling Issue in Iceland}

In Iceland, the culture of whaling, such as it is, is an invented tradition emerging from the recent conflation of a business enterprise with the body politic of a nation-state that derives its economic viability from fishing, fish processing, and the sale of related technologies. During the 1980s, media reports (growing more biased with time) about international anti-whaling protests and the partisan fights in the annual IWC meetings created the view that sentimental animal lovers and profit-driven environmental NGOs were 
to blame for the frequent political deadlocks. A 1982 debate in the Alping (Icelandic Parliament) about whether to abide by the IWC moratorium on hunting scheduled to take effect in 1986 (supported in the end by a majority of one) and U.S. pressure to change subsequent plans for a four-year whale hunt to begin in 1986 (ostensibly for scientific research permissible by the IWC's at times vague rules) became taken for evidence that Americans were largely and hypocritically responsible for the anti-whaling movement. When, in November 1986, two American activists from the Sea Shepherd Conservation Society (founded by Canadian Paul Watson, formerly a lead figure in Greenpeace) sank two of the four whaling boats at berth in Reykjavík harbor, Icelanders experienced the protection of their national borders as pierced by what the media called an act of terrorism. In March 1989 television broadcast of an Icelandic-made pro-whaling documentary allegedly funded (Icelandic critics charge) by the state triggered a powerful outpouring of anger in Iceland and solidified people behind their government. The weight of all of these events, together with news of contracts for foreign fish sales possibly cancelled in response to calls for boycotts against Icelandic businesses, the last Icelandic whale hunt in June 1989, and other events, minor scandals, heated debates, and satirical and cynical remarks woven through everyday conversations made Icelanders aware of and embody with varying degrees of acquiescence their makeover into the transnational discursive category known as a "whaling nation."

The antagonistic exchanges during the 1980s between foreign national governments, environmental NGOs, and people opposed to whaling on the one hand, and the Icelandic state and majority of the nation's quarter-million population on the other hand, created an ideational contact zone-a discursive location marked by incommensurability and self-vindication —out of which emerged the politicized, stereotypical figures of the whale, the whaler, and the environmentalist. What had once been an unremarkable and little-known post-war business making a modest one-per-cent-of-GDP contribution to the national economy (compared with 70-80 per cent earned through fishing industries) had become by the late 1980s the hypersensitive touchstone of national identification. While knowing full well that whaling itself has not been of historical, cultural, or economic significance, many Icelanders can still be provoked to anger should a foreigner question their country's pro-whaling position. They have accepted as true their government's argument that to hunt whales is a sovereign right, justifiable by science as an appropriate and rational use of nature defined as a capitalist economic resource. More specifically, 
they have accepted their government's assertion that not only are sovereignty and property rights at the dispute's core, they as well require protection.

Most Icelanders think, or have been persuaded to think (the difference in phrasing cannot be neutral), that actions taken to end the killing of whales are motivated by an irrational, over-emotional anthropomorphic belief in the sacredness of what are sarcastically referred to internationally in the rhetoric of cynical reason as "mediagenic megafauna." However, environmentalists argue that film and television imagery of large mammals help raise environmental awareness about wildlife and the life of oceans. Nonetheless, critics of the anti-whaling movement consider such imagery to be a dangerous aestheticism leading to a naïve, protectionist attitude toward nature. They would prefer whales be defined primarily as non-sentient raw materials-not unlike cows, to which they liken their supposedly limited intelligence-for the commercial market. Unless one is deeply partisan in such matters, neither position appears wholy untenable: an advisor from the Danish delegation to the IWC commented to me in 1992 that each side was a little bit right, thus implicitly acknowledging the more complex moral and conceptual terrain lying behind the dogmatic certainties of public, political discourse. Yet such truth claims, all too generalized and overstated to count for more than partisan rhetoric, are taken by their adherents as matters of indisputable fact distinct from the ideology or wrongheadedness of their opponents.

The Icelandic government has pursued its pro-whaling policies without appeal to cultural arguments, despite the fact that a non-Icelandic anthropologist and advisor to international whaling interests suggested they submit cultural impact assessments to the IWC. Such assessments are admissible under IWC protocols established in the late 1970s to handle aboriginal whaling (triggered by a controversial ban on the Alaskan bowhead whale hunt); however, they must define whaling as traditional in some sense (either for subsistence, cultural, or ritual purposes), and distinct from commercial whaling. The rhetorical strategies used by the Icelandic government have consistently emphasized national-sovereignty and free-market arguments, supported by appeals to the scientific research of the Marine Research Institute and the ideal of "rational management of ocean resources." They argue that the fin and minke whale stocks Icelanders most recently hunted are not endangered and hunt quotas are sustainable. While the Japanese and Norwegian whalers have argued unsuccessfully for the creation of a category of "small-type coastal whaling," modifying the definition of aboriginal whaling to meet their own interests, the Icelanders have placed virtually no effort in that direction. 
While some twenty families in the north used to hunt the small minke whale as part of household-based multi-species fishing economy, they received little economic or political support from the government. Rather, the political drive behind Icelandic whaling politics has been in defence of the one large whaling company, Hvalur hf., owned by a prominent businessman with strong links to the right-wing Independence Party (Sjálfstaedisflokkur) who has also owned trawlers, processing plants, and an insurance company as well as served on corporate boards of directors and been a dominant shareholder in BP oil. Since Iceland created a stock market in the 1990s, he has also become a partner in a lucrative investment firm.

Icelandic whaling management is defined in Iceland as an example of their country's modernity and the culture it exemplifies sits squarely within the hegemonic discourses of capitalism. The public response to Keiko was thus formed in a cultural context already constructed within the globalized discourses of the politics of whaling that defines an Icelandic identity vis-à-vis whaling as "rational." It seemed for a number of years that the choice for Icelanders was clear and the difference between the pro- and anti-whaling constituencies starkly black and white. As the minority of Icelanders who opposed whaling or who doubted their media's and government's representations and motives learned, discussing shades of grey was difficult in such a heated political climate. During the 1990s, however, whale hunting was becoming the just past and whale watching rapidly becoming a significant part of Iceland's future as a newly popular international tourist destination. While the owner of Hvalur hf. argued that killing whales and watching whales were compatible activities, those who operated whale-watching boats or were otherwise connected to tourism believed that watching and killing could not coexist without Iceland's international reputation and their own business enterprises suffering. For the first time, references to a "pro-whaling lobby" began to crop up in everyday conversations, indicating rifts in the nationalistic solidarity backing pro-whaling views.

Although its repeated threats to resume whaling weren't acted upon until 2003, the Icelandic government continued over the intervening years to assert its sovereign right to hunt whales off the country's coast. Nonetheless, thenPrime Minister Davíl Oddsson, of the pro-business Independence Party, managed with careful political manoeuvring to avoid giving in to the pro-whaling lobby's demands without ever indicating where his actual support resided. Thus, Icelanders were surprised when he accepted the American-based Free Willy/Keiko Foundation's proposal to return Keiko to Icelandic waters, and 
people I spoke with could only speculate about his reasoning. However, a Canadian-made news show gave one explanation I never heard in Icelandthat then-U.S. President Bill Clinton had endorsed the proposal during a meeting between the two political leaders.

The international story of Keiko's return and planned release does not easily fit into the binary logic of pro- and anti-whaling since those who oppose whaling both in Iceland and internationally were not necessarily in support of returning Keiko to the wild. Those involved with the live display of sea mammals, for example, were divided over the appropriateness of release, given the odds against its success and the potential for more pressure to rehabilitate other captive animals. Some animal rights and anti-animal captivity activists supported the plan while others thought it a cruel way to treat a domesticated whale. Icelandic public opinion about Keiko's return was mixed. Certainly there was opposition, not to mention cynical humour toward Keiko, but there was also a surprising amount of support. A poll reported on 18 March 1998 in Dagbladid Visir indicated that about $53 \%$ of the population favoured bringing Keiko to Iceland, while $20 \%$ was opposed. Support for whaling dropped slightly at the time to $75 \%$ although it remained within the $73 \%$ to $82 \%$ range documented since the mid-1980s. Those supporting Keiko's return cited economic reasons: it would be good for Iceland's international image and it would increase tourism. For others, it was a harmless idea and heart-warming story that would please children: Why not?

\section{The Cultural Politics of Whales and Whaling}

During the 1980s, at the height of the whaling controversy, displacing irrationality and over-emotionality onto the figure of the foreign environmentalist momentarily purified Icelandic self-identity of blame, left intact the modern Imaginary of romantic nature in cultural and national discourses, and kept the techno-industrial uses of nature largely (although not entirely) beyond critical examination. But contradictions inevitably arise when emotions-in this case, in Iceland, those associated with whales and environmentalism in general-are politicized and treated as if they were rationality's opposite when they are, more accurately, a central component of everyday perception and experience.

Situating the source of domestic problems outside Iceland's borders has played a long-standing role in modern identity-making, dating back at least to the seventeenth century. In 1609, Árngrímur Jónsson published Crymogeea, his 
response, written in Latin for a foreign audience, to accounts then circulating in Europe and portraying Icelanders as bestial, ignorant, and enthralled by superstitious beliefs. During the post-Reformation reordering of power relations within Europe and the early outward extension of modernity's institutional clusters, Iceland served as a peripheral Other for the European centre as it consolidated into a nexus of absolutist states. According to historian Sumarliai Ísleifsson, Árngrimur's outrage at this dishonoring of Icelanders laid the basis for the narrative content of nationalist discourse still mobilized in the present. Janus-faced, like nationalist imaginings elsewhere, Icelandic nationalism looks back to the golden age of the Icelandic Commonwealth, prior to foreign domination by Norwegians and Danes and as inscribed in the Icelandic sagas. Simultaneously, it looks forward to a future shaped by Enlightenment values of reason and progress through human efforts to dominate nature, and later, progress through independence from Danish rule and sovereign control of natural resources. A concomitant Romantic sensibility emerged in 18th and 19th century poetry and 20th century painting that strove to transform the land into landscape, thus materializing the national sublime. The nationalism which in 1988 my Icelandic friends identified as their response to yet another instance of, in their view, foreigners mis-recognizing Iceland's achievement of full modernity on par with that of Europe and the United States, flows from this historical interweaving of aesthetic, utilitarian, and sovereign objectifications of nature. In other words, the whaling issue has since its inception been conceptualized in modernist terms which posit nature separate from culture. Such an intellectual feat of purification is challenging to maintain in the face of the on-going hybridization of what Latour (1993) calls nature-cultures. Keiko thus constellates the shift, already underway with the development of whale-watching tourism, of the figure of the whale from a matter of fact to a matter of concern. Keiko's presence has in this sense been interpreted within a larger anxiety about a seemingly dangerous rupture of reason and rationality from which the nation must protect itself.

Examining the discourses surrounding Keiko allows a glimpse into the workings of the modern constitution (Latour 1993): Keiko's presence in national waters demanded from Icelanders the ideological effort to re-stabilize the rhetoric of reasonableness on which their identity within the cultural politics of whaling had relied but which their own mixed responses to this "special" whale had undermined. It is precisely because Keiko has not been successfully confined within politicized categories of thought that his image becomes so fascinating for cultural analysis. While he may occupy the same space as the U.S. NATO base, the cod wars with Great Britain, or the medieval saga manuscripts 
in serving as a point of discursive tension about the nation (cf. Pálsson and Durrenberger 1996), he fails to constellate it in the same manner. Keiko destabilizes both pro- and anti-whaling rhetoric in ways that reveal how people engage in moral reasoning by means of nature. The hegemonic paradigm about whales which diminished their sentience and disavowed the supposed emotionality of anthropomorphism, wavered. Other cultural logics-that affective bonds could be formed with animals, that science (this time medical/veterinary rather than management biology) could act in support of an animal's welfare rather than that of the state-were mobilized, triggering public debate.

Some Icelanders criticized Prime Minister Oddsson's decision to accept Keiko and took it as a sign that whaling would not be resumed. The author of this 29 April 1998 article in Dagur used what for him is the farfetched idea that whales are capable of thought as the basis for his satirical jibes:

Halldór Runólfsson's comments about the killer whale Keiko have now become infamous, but in Morgunbladid the other day he was quoted as saying that Keiko was without a doubt a "thinking animal." The Chief Veterinary Officer reached this conclusion after having looked deeply into Keiko's eyes.... The Chief Veterinary Officer looks into Keiko's eyes as part of official business, but he was supposed to be examining the health of the animal at the behest of the government, especially Davía Oddsson who has been an enthusiastic proponent of Keiko's move home.

It is clear that the Chief Veterinary Officer has given the prime minister a positive report about that thinking animal, Keiko, because it was no sooner than this report had been given that the government changed its mind about resuming whaling next summer....

Davíd is, it seems, the kind of person who won't allow the hunting of 'thinking animals.' He has himself declared that his dog Tanni is a thinking being, a good friend and one of his main advisors. The fact that Tanni is one of Davíd's main advisors tells us much about many of his party colleagues with whom the prime minister chooses not to consult. They must not be 'thinking beings.' There have however, as of yet, been made no suggestions about the hunting of these men.... Those who are the most excited about the resumption of minke whaling must then ask the Chief Veterinary Officer to go and look into the eyes of a few minke and hope that, unlike in the case of killer whales, the doctor won't state that they are 'thinking beings.' Then David and Tanni would perhaps allow for the whaling to be resumed! 
In September 1998 Keiko arrived into this shifting cultural landscape accompanied by a bevy of foreign media that once again brought Icelanders and the subject of whales into international focus. Local children were granted a break from school. They lined the streets of the small town in the Westman Islands where Keiko landed, waving and looking overwhelmed in Life magazine's photos as the killer whale was transported down the hill from the airport and to the dock where he was then lowered by sling and crane into the North Atlantic. At the time Icelanders asked themselves, what did it all portend for their identity as a nation, the future of whale hunting, and children's emotional responses to killing animals for a living? In a 12th of September article in Dagur surveying the opinions of four cultural commentators, a journalist poses the question, "Hvad táknar Keikó (what does Keiko represent)?":

Keiko has come "home." At workplaces all over the country people left their desks so they could follow the arrival of this most famous of whales, as if the television was broadcasting the handball finals. Does this circus represent a changed attitude among Icelanders about nature and what will this change in the discussions about the utilization of the whale stocks?

Once Keiko settled into his custom-built training facility in a bay adjacent to the harbor on the island of Heimaey-in English, "Home Island", an irony that no one missed-he soon dropped from headlines and conversation. The intense, emotionally fraught speculation that I encountered in September 1998 about the effects of his presence faded from memory. Cynical humor and a professing not to comprehend "this Keiko madness" had become the common means for Icelanders to distance themselves from what now tends to be viewed as nothing more than a cartoon or the doomed folly of rich Americans. Probably the most often repeated joke about Keiko suggested making him into 16,000 meatballs, or eating Keiko fast before his meat became old and tough. Some people call Keiko a pet, while others thought his only practical use could be as a tourist spectacle.

Nonetheless, despite this distancing, Keiko triggered an underlying anxiety and ambivalence. In part it stemmed from empathy for a helpless animal being forced by Americans against his will (if whales have wills, a point which shouldn't be quickly dismissed) out of the comfortable world to which he had grown accustomed. It made of him a boundary figure troubling the moral simplicity of pro- and anti-whaling positions. Referring back to my introduc- 
tion, I do not see this move from indignation to ambivalence as a form of unidirectional cultural change or historical evolution but rather as part of a continual moving toward and away from rigidly codified ways of thinking about nature within a hegemonic political economy demanding nature be passive and manipulable. In Latour's terms, whales and whaling had changed from a matter of fact to a matter of concern, and the many possible ways in which whales could be imagined within Icelandic culture have surfaced, their contradictions opening up possibilities for new ways of thinking.

\section{Tropes of Ambivalence}

I turn now to a series of five tropes I see as emergent in Keiko's Icelandic saga. While for the sake of analysis I will illustrate each trope with reference to only a few sources, their selection is based on analysis of over 700 newspaper articles, editorials, editorial cartoons, and opinion pieces appearing in the Icelandic media from February 1998 until May 1999. I have selected them on the basis of how clearly they represent not only meanings found in the media, but as well in the everyday opinions I encountered in interviews and conversations since Keiko's arrival in 1998. Because of Iceland's small size (2006 population: $300,000)$ and high degree of public participation in civic debate, the gap between media and public perspectives is not as pronounced as in larger countries. Icelandic citizens have greater access to publishing opinion pieces and indepth articles in the newspapers. Thus, media representations provide excellent access to the conversations Icelanders have with one another: I have found them to be more illustrative and elaborated while similar in meaning and intentionality as face-to-face conversations I have had. This is particularly germane in a circumstance where most Icelanders' direct experiences of whales and whaling are quite limited when compared with the considerable power the media and government have exercised in shaping nationalist interpretations.

The following tropes are locations where Icelanders continually do the cultural work of purifying their cultural identity and displacing blame and responsibility onto a scapegoat, most likely but not always a foreign source of categorical pollution. Keiko transgressed various borders of Icelandic identification, triggering anxieties that had to be conceptually calmed, and in his representation is captured the quickly shifting landscapes of cultural creativity. Each trope, however, only embellishes rather than resolves the experience of anxiety and ambivalence about appropriate relations to whales because the modernist rupture of nature and culture is never resolved. Nonetheless, trac- 
ing Keiko's translation into different cultural logics dissolves the ideological opposition of emotions to rationality and comes closer to capturing the dynamics of thinking/feeling in cultural practice. The tropes concern such modernist narratives as freedom versus confinement; the search for home and family in a world saturated with migration; repatriation of cultural properties to restore cultural wholeness; fears of alienation and loss triggered by media spectacle; the ever-shifting boundary between human and nonhuman; and the relation of science to profit, and profit to moral values. These tropes crosscut the easy moralizing certainty that political demonization of foreign environmentalists has given.

\section{The Search for Love and Wholeness}

By characterizing Americans as overly sentimental and emotionally infantile, the first trope attempts to normalize reasonable limits to both loving attachment and (economic) rationality. This trope is also the central theme to both the Free Willy movies and the Free Keiko movement. At the heart of the first Free Willy movie is a psychological truth about children's fearful relationship with adults. Children fear abandonment and fear their own sense of weakness and vulnerability. Learning not to be fearful but rather to trust, despite a hostile world, in the bonds of the modern nuclear family's love and strength is the movie's overall message. In Free Willy 2 and 3 similarly redemptive stories are told, always with the emotional bonds of family and friendship winning against profit-driven aquarium owners, oil industrialists, and rogue whalers. In the first film, order is restored when Willy is released from captivity and reunited with his natural family. Meanwhile, the boy accepts his adopted family as his natural place of home and belonging.

In Icelandic, in common with other languages of northern Europe, the word "home" (Icelandic: heim) is freighted with significance: a physical place as well as a state of being-a place of nurturance, refuge and ease, where "one's affections centre" and where people hope to most know themselves (Rapport and Overing 2000). It is against this threat of disconnection and dislocation that the idea and ideal of home is rendered desirable in Western modernity. John Berger figures modernity as exile: more than political banishment, exile is both a consequence of modernity and a metaphor for the modern condition (Papastergiadis 1993). Longing for home, then, may be a way to resist the sense of transience in an increasingly globalized world. As American as the particulars of the Free Willy movies are, their narratives nonetheless speak to a transnational experience of modernity as separation and loss. 
In contrast to home, the foreign place in Iceland evokes both desire and fear. Since the late 1960s, more young Icelanders travel abroad and experience life outside the borders of their small society than ever before. Returning home becomes a quandary for some since as much as they might miss friends, family, and sense of homeplace, they also have experienced return to such a small country and harsh climate to be confining, and/or imposing limits to their careers and lives. For example, when championing the creation of the genomics firm deCode, supporters claimed it would reverse the brain drain as Icelanders best and brightest sought better opportunities elsewhere. While Keiko's return "home" is commented upon and satirized, the darker, more fearful aspect of his life story-one of endless displacement, nomadic wandering, alienation from family, and exile-is left unsaid.

Following on Drummond (1995), I have placed Free Willy 1, 2, and 3 with other boy-critter flicks such as E.T. to argue that at heart these movies concern not the relation between humans and non-human sentient nature, but rather the relations between members of a nuclear family using an interchangeable third figure such as a whale or an alien. For Drummond, movies are myths, good for thinking about what makes human identity in relation to animals and machines. However, Icelandic critic and editor, Hermann Stefánsson (1999) reads the Free Willy films from within the cultural politics of whales and whaling. He argues the films share with the campaign to "Free Keiko" a common ideational space in a postmodern American Imaginary that consumes nature as spectacle. He connects the Free Willy movies with The Truman Show, the Australian director Peter Weir's prescient satire on reality television and reality as television, and Wag the Dog, a satire on the excesses of spin in presidential politics. In brief, he argues that Americans inhabit a media-generated simulacrum that alienates them from nature and encourages them to sentimentalize it.

Stefánsson's analysis strives to distance Icelandic reality from the theme of home and belonging found in the Free Willy movies although he acknowledges that Icelanders are susceptible to similar absorption into the simulacrum. However, I see the theme of home and belonging as deeply embedded in Icelandic experience: despite their simple and sentimental morality - the movies were made for children-they nonetheless resonate with a deeply held desire for the shelter of home. Icelanders, too, now cope with the problems of romantic love and the emotional intimacy it demands, and with familial conflicts and divorce. Further, the theme of returning home is a potent one for Icelanders. Given that the concepts of family and kinship 
can be mapped onto the nation, and home mapped onto homeland, returning home means both a return to the family and the nation. Yet to admit to this common ground between Americans and Icelanders would undermine the political need to treat Free Willy, as well as the Free Keiko campaign, as both foreign and deluded: in other words, Icelanders live in reality but Americans are caught in the reflections and simulations of Plato's cave.

I had encountered a similar way of thinking during the question period following a public talk I gave at the University of Iceland (1998) a week following Keiko's return. ${ }^{1}$ The talk had been more generally concerned with the cultural politics of whaling, but a questioner had wanted me to say something quite similar to Stefánsson's analysis in relation to Keiko. Instead, I responded with what I have written here regarding Keiko's "homecoming" as resonant with an Icelandic dilemma. The small shock of recognition this produced in the audience, although not shifting any deeply held convictions, momentarily yielded a point of convergence between two adversarial positions. Latour writes against the idea of the simulacrum: he argues that modernist thought is premised on Plato's allegory of the Cave, an allegory for knowledge which can no longer hold. The role of the simulacrum, in this case, was to produce distance and difference, whereas my own analysis had suggested a diplomatic point of similarity.

\section{Emotions in Human-Non-human Relations}

The second trope acts to set the appropriate degree of agency and intelligence to attribute to animals without seeming to be overly anthropomorphizing. It also strives to define a proper emotional distance where human-non-human relationships are concerned. To this end, journalists monitored reports of children displaying sentimental attitudes toward Keiko and other whales as if such responses were a sign of identity loss. On 12 September, two days after Keiko's arrival, the following commentary appeared in the opinion column Víkverji in the largest newspaper, Morgunbladid:

Víkverji finds the reaction of the younger generation to the arrival of Keiko quite interesting. This animal now appears to reside in the hearts of children, as Lassie and Skippy did here years before. Morgunbladid carried some interviews with some boys from the Westman Islands, who said that they were completely against whaling, at least if those whales were to be eaten. When asked why whaling should be banned, they replied: because they are so famous and cute. The arrival of Keiko could 
result in the upcoming generation of Icelanders not wanting to resume whaling, not because of international pressure but because this new nation will care so much for the whales! At least it is interesting to hear this point of view expressed in the islands, where people live by hunting and fishing all kinds of sea creatures.

When Víkverji lived in Britain he was surprised to learn of the attitude of Britons to the puffin. Britons look at the puffin in a similar manner to the whale, as a symbol of natural beauty besieged by human greed. Environmentalists go on protest walks to save the puffin, etc. This opinion can of course be traced to the fact that the puffin is endangered in Britain, although he is not in Iceland, not any more than the whales are endangered in the Icelandic oceans. Now that Westman Islanders have been infected by foreign love for whales, we can ask when they will also stop hunting the puffin out of love. ${ }^{3}$

But for all the talk about how Icelanders must be able to kill animals to survive and avoid sentimentality at all costs (although only a tiny percentage of the population is actually engaged in killing for food production), the trope opposing emotions to practical reason is more strongly associated with whales than it is with other human-animal relations. Defining whales as economic resources is not the maintenance but rather the creation of a politicized cultural value that strives to purify economic logic of the morality of killing. The politics of whaling has entrenched an attitude inconsistent with historical practice requiring people to cope with their emotional relations with farm animals in the face of the necessity of killing. My point isn't that all Icelanders experienced such coping similarly - psychological differences prevail. Rather, any stereotypical image of a consistent cultural self that does not feel the act of killing needs to be viewed in this context as politicized.

In the pre-modern farm economy, Icelanders could and did form relations with animals - their dogs, sheep, horses, and cows. Farmers had and have no difficulty in recognizing personalities and intelligence in their animals. Such relations are fictionalized in Gunnar Gunnarsson's 1937 novel, The Good Shepherd (Adventa), in which the author portrays the close relations between a farmhand, his dog, and his leaderram, a category of sheep bred for centuries specifically for its intelligence and perception. However, Icelanders did not form relations with creatures from the sea since it was not a physical location of sustained human activity, as anthropologists Gísli Pálsson and Haraldur ólafsson remarked in newspaper interviews. Nonetheless, when the live-whale capture 
industry began in the 1970s, a few Icelanders overcame fear in order to care for the killer whales and subsequently formed social bonds with them.

One case was described without cynicism in a lengthy 19 April 1998 article in Morgunbladid profiling a man who cared for a killer whale eventually moved to a marineland in France. Over the two months they were together, Elías' fondness for the animal came to strike his friends as going too far:

Elías visited her at least twice a day and each time stayed a good while. He also visited her at night. Many of the fishermen in this place had really had enough of this friendship and at a porrablót that year Adalheidur Geirsdóttir composed these lines: "Elli and Jóhanna went into the beautiful sea and he promised her undying love, she cried out with happiness: I give you my hand. Cried Elli then: I will never leave the water without you!" ${ }^{5}$

Composing satiric poetry (the rhyme is lost in translation) to comment on the unseemly behaviour of others has a long history in Iceland. At the public occasion of the mid-winter feast of porri, Elías was reminded that his affections for the whale had gone too far.

\section{Alienation and Spectacle}

Anxiety about American cultural domination finds expression in a third trope that attempts to mediate the experience of alienation and spectacle associated with American media. It seeks to establish codes of their restrained and discriminating consumption. In line with Stefánsson's (op.cit.) acknowledgement that Icelanders are becoming absorbed into an American simulacrum, people go to movies and watch TV and learn much of what they know about the United States' cultural life through them. Criticizing perceptions thus formed occurs in other contexts, for example, when the Icelandic government gave its support to the U.S. military invasion of Iraq. Sometime early in 2003, an anonymous stencil artist working under the English-language logo "Eye Information" sprayed the following graffiti (in Icelandic) along the main street Laugavegur:

If you want to wage war, you are going to see war. The foreign secretary of Iceland and other persons in authority seem to be excited about war, but have they ever seen war? Except on the television?

How to adapt to the media and decide what is benignly acceptable and what unacceptably foreign has become one area for Icelanders to do their cultural work. 
A dominant argument in Iceland in support of Keiko's return asserted that tourist revenues would be good for regional and national coffers. A friend told me it was an example of an Icelandic attitude known as "verbúd." The term refers to the fishermen's huts erected historically at the seashore and metaphorically evokes an attitude of making a quick profit with no long term goal or commitment. But when it eventually sank in that Americans were not going to pay thousands of dollars to fly to Iceland and the whale wouldn't be a tourist spectacle many found the whole experiment pointless. While the Ocean Futures people continued to put money into the local economy by hiring locals, buying herring from the fishermen, and shopping locally, Keiko did not generate much in the way of tourist dollars during his stay in Iceland.

It is certainly ironic that a whale famous for being a spectacle was in fact invisible to the average visitor. Only visiting heads of state, celebrities, and fashion models from the Ford Agency had the opportunity to be up close and personal with the whale when he resided in his Westman Islands baypen. The necessary behavioral logic of minimizing human contact fit well, in this case, with the entertainment world logic of retaining Keiko's status as a celebrity with whom only the rich and famous could interact.

This way of thinking sits oddly with another, more uncomfortable, experience around spectacle. Some people reported feeling discomfited by the image of their country that foreigners created during the September 1998 media frenzy around Keiko's return. Icelanders felt put on display but in a manner over which they had no say or control. The stereotypical clichés and speculations about Icelanders with uncontrollable impulses to kill whales wounded national pride because it did not mirror their sense of self. The experience paralleled what happened during the 1980s when the sloppiness of foreign media reportage helped to make Icelanders into a whaling nation. In response to this coverage, an opinion poll taken in October 1998, a month after Keiko's return, showed that support for a return to whaling had soared to $82 \%$ from the low of $75 \%$ reported the previous March.

Nonetheless, mocking the stereotype of themselves as random butchers of whales figures in everyday jokes in Iceland. Playing to stereotype for the sake of fun, the Icelandic state radio broadcast on April Fool's Day 2002 a news item about farmers on the south coast shooting at Keiko because he was (so the joke went) a pest stealing all the fish. Mixed together in this story - which, though I missed it, my friends assure me was quite convincing and briefly fooled the audience - was an urbanite disdain for the intelligence of farmers and a reference to the dubious claim that whales are competitors for fish stocks properly 
belonging to Icelandic fishers. The story came within a hair's breadth of hitting the international media as a real event rather than a satire, and the damage control it required was a reminder to Icelanders that their country was no longer isolated by geography and language from the rest of the mediated world.

\section{Culture, Genuine and Spurious}

A fourth trope for sorting out what is genuinely Icelandic and what is spurious and foreign concerns the repatriation of cultural properties. A satirical article from April 1998 in Vinnan about Keiko the Hollywood actor returning home jokingly compares Keiko to the medieval saga manuscripts ${ }^{7}$ that are a key symbol of the Icelandic nation:

\section{The Hollywood Actor Returns Home}

Our famous cousin, the Hollywood actor Keiko is returning home. The only Icelandic actor that has really made it in the land of glitter and glamour. Keiko's career peaked a few years ago, as the whole world knows, when he played the friend Willy in a touching family movie that struck gold around the world. And even though Keiko has grown out of being Willy, and has become a bit fat, tired and grey from all of his homesickness, and the glow of his fame has started to wear off, we have decided to invite him back home.

of course Keiko is welcome here. He is after all one of us. Icelandic through and through (í húz og hár lit.: "in hide and hair"), or more correctly, blubber and fin. A world famous actor that attracts crowds of people wherever he goes, he must be able to put some money in the depleted government coffers. Men are already beginning to plan the welcoming ceremony. Only once before has something this precious been returned to us: the manuscripts. So, a ship will accompany the return of Keiko, just as an official guard ship protected those precious manuscripts upon their return. Then the crowd at the harbour will cheer when Keiko is hoisted with a huge crane from the body of the guard ship over to a floating reserve which will be attached to the pier. There he can finally swim and paddle around, relaxed and happy, drinking Icelandic sea, free from the stress of show business, the glamour, the glitter. Instead, he will have the real sea business to deal with. Tourists will come and pay a fortune for the chance to stare at the fellow in the tub. Then, and only then, will his fins finally rise. And he can die a happy whale, finally resting in the Icelandic sea. 
The comparison of Keiko to the nationally sacrosanct medieval saga manuscripts uses a high culture/low culture distinction to satirize not only the Keiko story but also the general fascination with the cult of Hollywood personality occupying a niche in Icelandic cultural life. The manuscripts are authentic culture and worthy of respect, but Keiko is anthropomorphized as an Icelandic citizen and Hollywood has-been-successful but now fallen-for whom the sagas are presumably not of value since his sojourn in America has changed him from robust to lazy. The writer is poking fun at any Icelander who would think the values of money and media fame are as worthy of invitation "home" as the manuscripts. As with the trope that pits family against profit, the disruptive power of greed on the social order is touched upon.

The idea that objects, including animals, need to be returned to their proper cultural locations figures in controversies over museum collections and their colonial pasts. To the extent that these are demands arising from a desire to restore things to their 'natural' state, they share a common impulse with other romantic, nostalgic responses to modernity. The drive to restore the past has been a widespread reaction to modernity's destructive impulses that has taken root in Iceland as elsewhere. Restoration and the return of cultural properties thus resonate in the Icelandic cultural Imaginary, and require ideological work to make the Keiko case of a different order.

While the saga manuscripts and their history are the centrepiece of historical displays at Icelandic Cultural House, another less auspicious attempt at repatriation concerns the bones of the national poet and naturalist, Jónas Hallgrímsson (1807-1845). Hallgrímsson died in Copenhagen; a century later, shortly after Iceland became a republic, politicians planned a cemetery for the nation's heroes at the sacrosanct national site of pingvellir (cf. Hálfdanarson 2000). The scandal that erupted when the authenticity of the bones was contested led to abandonment of the cemetery plans. Since Hallgrímsson died childless, recent suggestions that DNA testing confirm identification are no closer to solving the matter. Jón Karl Helgason, author of a cultural analysis of the poet's bones (2003), commented to me on the irony of a recent campaign to have Keiko's bones-now buried in Norway-moved to the whaling museum in Húsavík, northern Iceland (pers. comm.). While the whaling museum does document the history of the whaling industry in Iceland, its founder is a successful entrepreneur in whale watching and a vocal opponent of the 2003 return to minke whaling in the north, arguing that the whalers' actions were causing marine mammals to retreat from view. Keiko's bones would have thus added to the construction of the whale as tourist spectacle. 


\section{Wild Children}

A fifth and final trope I call the "wild child" in order to connect Keiko to stories of feral children such as the 18th century's Victor de L'Aveyron (Lane and Pillard 1976, Shattuck 1994), the 19th century's Kaspar Hauser (Kitchen 2001, Feuerbach 1997), and the 20th century's Kamala (Singh et al. 1966) and Genie (Rymer 1994). These children grew up isolated from human sociality and became figures of profound public curiosity and speculation. As contested objects of experts promoting their own theories of learning and human nature, they served as focal points for anxieties about human existence projected onto the moral, political, and scientific discourses of their times. As was true for Keiko, their lives were worsened by custodians who believed care-giving was consistent with scientific experimentation. Like Keiko, they were boundary figures blurring the modernist opposition of nature to culture, and science to sentiment.

The wild child trope doesn't involve Icelanders directly. Iceland and its inhabitants were merely a stage set for a made-in-the-USA drama involving rival forces in the commercial world of sea mammal management and the rich iconography of dolphins and whales in the American Imaginary (Bryld and Lykke 2000). If anything, the wild child underscores an ambivalent sense in Iceland of desiring the pleasures of Americanized media and consumer goods but fearing the dependence on and vulnerability to the seemingly whimsical demands emanating from outside the country. In this context, the figure of Keiko, as symbol of foreign penetration, continues the cultural work that the U.S.-run NATO base $50 \mathrm{~km}$ distant from Reykjavík had played until the end of the Cold War.

The wild child trope concerns the familiar debate about nature versus nurture, as it intersects with Enlightenment metaphors of culture and cultivation linking promotion of biological growth with acquisition of civilized behavior and thought. Scientists subjected wild children to scrutiny in order to test particular theories of human nature. Interestingly - given the desire of Keiko's handlers to return him to a state of nature-empirical scrutiny of wild children over the last centuries helped unsettle long-established assumptions about inherent human nature and demonstrated, in one example, the accuracy of Vygotsky's theory linking language and thought (McCrone 1993). In this view, a child's early acquisition of language entails internalizing speech, such that an inner voice- the sense of self-develops. Attempts to teach feral children to speak have assumed (wrongly, in McCrone's view) that such teaching would "release" or "unlock" an innate capacity for speech which would then 
provide access to the children's internal thought world. McCrone cites the commonalities of these cases as evidence for the lack of such a thought world or sense of self: the children all lacked memory, self-awareness, and reason; they did not give special attention to human speech nor identify with other humans; they did not exhibit normal sexual responses and, finally, they walked on all fours rather than stood upright. It would appear, McCrone concludes, that the qualities typically cited as the basis of a separate human identity must, in fact, be learned.

The Keiko narrative inverts the wild child story in terms of the direction that training must lead - he must change from culture back to nature-but his case raises similar unsettling questions about what is "natural" in a whale (or any other animal) and what, if any, is the boundary between humans and non-human sentient nature. Keiko's handlers had hoped to find his birth family so that he could (re-)learn that pod's dialect, a necessity for killer whale communal hunting. They also tried, unsuccessfully, to teach him to hunt and kill prey: Keiko was fed dead fish until his own death. These fundaments of supposed wildness were missing in Keiko, and his preference for human companionship-actually, male companionship since he rebuffed his female trainers-suggest that Keiko's own sense of self did not accord with the nostalgic modernist script of return to a nature purified of culture.

The drama of the Keiko story, such as it was, arose from the uncertain outcome of the experiment in backtraining. Taken from his pod at two years of age, Keiko might not have learned his pod's dialect, thus lessening his chances of forming the social ties upon which killer whales depend. Could a long-captive, performing whale be made wild again, its human attributes and attachments made to disappear by means of a schedule of repetitive training based on what are highly contingent and speculative methods and hypotheses? Or was his training program simply instilling new behaviors that Keiko could mimic without learning the underlying (highly cultural) goal of "wildness"? Would Keiko have survived the transition to the wild or would he have died soon after release? Would his birth family be found, accept and teach him those survival skills that humans had so far failed to do? Or would Keiko shun release, and continue to prefer the company of humans over non-humans? If the experiment proved a failure what would become of Keiko? Who would cover the costs of feeding him all that fish?

Despite what McCrone argues - that empirical observation discredits simplistic assumptions about human nature- the redemptive romance of restoring the categorical order of distinct nature and culture is still persuasive in the 
modernist Imaginary. Nonetheless, when it comes to whales and whaling, Iceland and the United States are located differently in the scientific, political, economic, and moral discourses to which the IWC gives rise. While in American discourse Keiko figures the boundary between human and nonhuman, in Icelandic discourse he figures the anxious national boundary between "us" and the foreign "them", as exemplified in Stefánsson's (op.cit) reading of Free Willy. Keiko constellates in each locale a differing nexus of fear, power, force, and dependence. Thus the figure of the wild child neatly captures how ambiguities inherent to the culture/nature paradox can harden into politicized dichotomies in historically contingent ways. Considering how $19^{\text {th}}$-century colonial and child-rearing discourses were rife with conflicting assumptions about the essential innocence or savagery of the native/child, the wild child trope speaks volumes about the production of Otherness through the image of a separate Nature.

of this final trope I can only give a brief sketch since its intricacies extend beyond the scope of my fieldwork. While I do not aim for in-depth coverage, I do endeavor to at least make Iceland visible in the background of scholarly works pertaining to the social worlds of captive animals in the United States. However, interviews in Iceland with Americans involved with Keiko's rehabilitation combined with text sources point to a number of interesting features. As well, a number of authors (Davis 1997, Desmond 1999, Green 1999) provide insight into the politics of the capture and display of sea mammals, an industry for which Iceland has provided the "raw materials", and suggest ways in which Keiko's story can be read as a transnational one.

When, under the Marine Mammal Protection Act of 1972, the U.S. government banned the capture of marine mammals in its national waters, zoos and aquaria moved their operations off-shore and spawned a new international industry of animal brokerage. Iceland was one of several locations where animals were captured and held until such time as sponsoring American-based businesses could "rescue" them-a loophole that legislation left open so that aquaria could still acquire new stock. Considering killer whales to be pests, the Icelandic government not only encouraged the live capture industry but also, for a time, requested that the American military at the Keflavík NATO base use them for target practice. The first director of the Keiko field team in Iceland, Jeff Foster, grew up in this live capture industry, and had travelled to Iceland in the 1980s to procure killer whales for American aquaria.

While Time-Warner contributed substantially to the Keiko Free Willy Foundation, a large portion of the financing —one estimate puts the figure at 
USD 10 million - came from Craig McCaw, a Seattle-based billionaire. At about the same time that Keiko was being prepared for his move to Iceland, McCaw attempted to intervene in the Makah grey whale hunt off Washington's coast by offering to fund community development projects if the Makah were to back down. They declined the offer. ${ }^{8}$

McCaw built his fortune when he sold his wireless communications company to AT \& T in 1994. He became Chairman of the Board and CEO of a venture capital fund focusing on wireless satellite communications, and partnered with Microsoft's Bill Gates and others in order to launch 288 satellites with the goal of providing high-bandwidth data communications via a global internet service. These plans never came to fruition, and early in 2002, McCaw withdrew his funding for Keiko's backtraining ostensibly after disappointment in the whale's progress. However, his faltering in the high-tech financial meltdown of 2001-02 could also have been a factor. The Humane Society of the United States stepped in to replace him.

In his biography of McCaw, the journalist Casey Corr found in Keiko a ready metaphor to characterize the billionaire's world-changing ambitions to liberate the masses: "McCaw wanted to sever Keiko's dependence on hand-fed salmon just as he wants to cut the leash that holds office workers to their desks. New wireless devices linked to powerful data systems would restore the nomad, allowing people to live where they wished and freeing them from the pollution and traffic jams of urban centers..." (Corr 2000:282-3).

In an interview broadcast on PBS in 1998, however, McCaw articulates a more ambitious technoscientific utopian view. Asked to explain what he sees as the moral imperative behind setting Keiko free, McCaw states:

...we asked the question, what is fair? What is right? And l've equated this to aliens from outer space coming to humans and saying, we would like to take some of you, or in fact taking some of us, and how would we react if they wanted to study us. And would it be that different. The orcas swim in space that we don't very well understand and of course in outer space we will face some day the moral dilemma of how to deal with aliens who land on earth, perhaps, if in fact what people believe is true-and we will have the same moral dilemma in exchanging people or creatures back and forth with them for understanding. ${ }^{9}$

McCaw's allegory is intriguingly consistent with what Mette Bryld and Nina Lykke (2000) note about uses of the dolphin figure in the space programs of 
both the United States and the former Soviet Union. His comparing orcas to aliens resembles how in these programs the deep ocean comes to be mapped onto deep space as territories of masculine adventure and exploration. The logic of social engineering that had informed attempts to civilize feral children and the "savage" Other is also evident in McCaw's sense of mission for the Makah and for whales. So, too, is the logic apparent in the various interpretations of Keiko's final, meandering swim east across the Atlantic to Norway in 2002, as I will now discuss.

Keiko's swim revealed the faultlines between different constituencies of marine mammal workers, illustrating different assumptions about (animal) nature and mirroring the competition among caregivers of feral children. When the Humane Society of the United States took over Keiko's care and training, one of their first acts was to fire Jeff Foster and his team. They argued that Foster used training techniques deriving from the live-display entertainment business that reinforced the whale-trainer bond rather than encouraged independence. A few months later, the new training team released Keiko for his meandering swim to Norway. According to the Humane Society website, however, his swim was anything but random:

On his "walks" in Iceland, he was free to leave or stay. And leave he did-taking off across the open waters separating Iceland from the rest of Scandinavia, swimming steadily for at least five weeks, almost certainly feeding himself, without human contact.

What must he have thought, in those immensely wide spaces?... Was he frightened? Perhaps a little, as one is when one first leaves the comfort of the familiar for the unknown of "real life." But he kept his head, and he steered true and came at last to another shore, in Norway.

In his final months in Taknes, he was free to come and go as he pleased. He explored his surroundings, interacted with his human caretakers, mugged for the occasional camera, even chased birds and fish. He breathed clean sub-arctic air, watched the days grow shorter and then longer again, felt the fury of storms and the joy of a boisterous breach, with no walls confining him....

He died as many might wish to die-suddenly, with little warning, happy and free and among friends. ${ }^{10}$

According to the public voice of the Humane Society, Keiko had the human-like agency to make choices: he chose freedom, and chose to stay in Norway (I 
heard Icelanders delight in the irony that Keiko chose to go to another whaling nation, reinforcing their belief that he was a rather stupid whale). While the Humane Society comments are directed toward the general public and fulfil the desire for a happy ending to Keiko/Willy's journeys, they also act to justify the controversial release. While Keiko was still swimming across the North Atlantic, Foster's team disputed the strategies employed by the Humane Society and expressed concern over the wisdom of release. Their 21 August 2002 memo indicates a history of conflict between the two groups of caregivers, consistent with disputes over care which arose in the cases of feral children. The detailed arguments put forth indicate, in the instrumental language of rational management, rival evaluations of behavioral observations:

The distance from Vestmannaeyjar [Westman Islands] and potential solitude of the animal represents a serious concern for the ongoing reintroduction effort and the long-term safety of the animal, due to a variety of logistical challenges, personnel issues, and potentially regulatory issues since the animal is no longer in Icelandic waters....

Our primary concern is Keiko's past failure to demonstrate an ability to forage independently in the wild. Although he was trained to eat live fish in the bay prior to reintroduction efforts, this behavior was conducted when humans provided live fish for him; there was not evidence of Keiko foraging independently in the bay.... While it is possible that foraging occurred and was not observed, based on extensive surface observations it is unlikely....

Another concern involves Keiko's reaction to boats. On several occasions last summer during the reintroduction effort, Keiko approached vessels other than the designated "walk" vessel....Although Keiko's presence at the boats during those periods was not usually prolonged, it sets precedence for this behavior to approach unknown vessels. If this behavior continues and he is in any way reinforced from vessels (either through primary reinforcement by the public feeding him, or by secondary reinforcement via reaction or interaction of people on the boat), it is quite likely that this problem will increase in magnitude and duration. ${ }^{11}$

Different images of sentient nature emerge from these two interpretations of Keiko's boat-tracking habits. According to the Humane Society, Keiko exemplifies rational choice theory by having chosen to become wild, and from that new state of wildness (that is, not constrained by authoritarian institutional 
structures), having chosen a lifestyle balancing a touristic appreciation of the oceanic sublime with performing his jobs as both tourist spectacle and scientific specimen. He is the happy native, living close to nature, appreciating the helpful human hand, and taking pleasure in posing for the cameras. However, according to Foster et al., Keiko had not yet learned to make the right choices appropriate for a wild whale. Still child-like, he continued to require administration by humans, his actions measured and evaluated, and his fate determined by the protocols of instrumental rationality. I find it difficult not to see echoed in both interpretations rival American approaches to foreign aid and capitalist development: nature's alterity is caught between neo-liberal fantasies of laissez-faire capitalism and state-driven development schemes.

Ocean Futures portrayed the Keiko project as an instance of scientific progress and environmental betterment, consistent with the modernist assumption that nature must be controlled by human reason and for human goals:

In our mind it would be inappropriate, no matter how popular Keiko was and no matter how big children's dreaming was, to spend so much money on one whale if more was not going to come of it. And we believe, this is all about scientific research, really understanding what's possible, understanding his family, where his family is, how they communicate, how the family unit works. ${ }^{12}$

In Iceland, the Keiko project was largely seen as driven by profit and entertainment, and as irrelevant to science. The idea that science and profit are not mutually exclusive had not been widely debated in Iceland until the late 1990s, when the publicly-traded genomics company deCode sought monopoly control from the Icelandic state over the Health Sector Database containing genetic and genealogical data (Árnason and Simpson 2003, Pálsson and Hardardóttir 2002, Sigurdsson 2001).

While the majority would prefer to imagine science as disinterested, when it comes to the international production of knowledge about whales, the rationale and funding for such science is shifting from the whale hunting industry to the entertainment industries running theme parks and whalewatching boats. Nonetheless, new scientific knowledge about North Atlantic killer whale populations and behaviors has come from the Keiko project, given that making detailed notes and measurements based on observation and sampling constitute scientific practice. Interestingly, in the scientific world, the boundaries between science for production (i.e., fisheries manage- 
ment) and science for consumption (i.e. entertainment industries) are blurred, since both derive from and serve an instrumental approach to sentient nature and represent what Latour calls "nature-cultures." Unknown to most Icelanders, the Icelandic Marine Research Institute and researchers from Sea World and elsewhere collaborated to compile information on the state of current knowledge about North Atlantic killer whale stocks, in response to a directive from the IWC. ${ }^{13}$

I am aware that I risk reinforcing the view from Iceland of a world gone mad, all for the sake of a whale. In that view, the charges, counter-charges, conspiracy theories, and machinations of a live-capture industry appear strange and disturbing. My goal in exploring the wild child trope is, rather, to destabilize any claim to authenticity, rationality, or unmediated access to a non-social nature that pro-whalers or anti-whalers could make. Whether in Iceland or the United States, the dynamics of identity and alterity are complex, paradoxical, and not at all reducible to the simple moral claims of right and wrong circulating in the whaling issue.

\section{The Predicament of Nature in the Modernist Imaginary}

Over the past years, indignation about foreign anti-whalers has fuelled nationalist sentiment in Iceland. As a modern emotional complex bringing ideology together with subjective identifications, indignation plays a role in creating collectivities, encouraging their members to derive their sense of being from demonizing any other collectivity they experience as a source of threat or unwelcome change. Indignation places the subject in the moral high ground, exempt from critical self-examination. In this way, I suggest, fear of the Other, when played upon through exaggerated narratives of the Other's power to destroy lives or livelihoods, takes on pleasurable qualities. The sense of belonging to a victimized collectivity mitigates the negative feeling of powerlessness and vulnerability that fear produces. Such a cultural dynamic concurs with Ernst Renan's oft-quoted observation, that "[w]here national memories are concerned, griefs are of more value than triumphs, for they impose duties, and require a common effort" (Renan 1990[1882]:19).

The ambivalence regarding Keiko that I have argued is manifest in Iceland exists because the modernist association of emotions with irrationality and over-sentimentality has made any spontaneously-felt (albeit still cultural) experience of non-humans immediately suspect. For Icelanders, feelings of empathy for a whale need to be couched in terms separating a rational 
Icelandic identity from a seemingly corrupt and irrational American one. This suspicion of emotionality in turn has raised challenges for biologists who, to give but two examples, wish to study animal behavior outside the accepted logic of resource management, or argue in favor of preserving natural habitats for threatened bird species as happened during the on-going campaign to stop a massive hydroelectric development in the highlands of eastern Iceland. In short, the politicization of the whale has limited the exploration in Iceland of human embodiment as continuous with the natural world, rather than nature as a constitutive Other.

Latour's reframing of what he calls the constitution shifts interpretation of these tensions. No longer cast within debates about rationality and emotionality, facts and values, the politics of truth claims becomes more apparent. Rather than assuming that anthropology can discern the validity of truth claims by siding with one scientist advisor over another, ethnographic work can be more fruitfully directed toward the on-going diplomatic negotiations between humans and non-humans, fraught as they are.

For a series of contingent reasons, Keiko's presence helped (albeit in a small way) to undermine the political solidarity behind Iceland's claim to the sovereign right to hunt whales, a claim already weakened by the profits accrued by tourism and the whale-watching sector. The government's move in 2003 to begin 'scientific' whaling-a move motivated by internal politics-supports my earlier assertion that no unilineal historical trajectory is at work. Rather, the government is once again attempting to harness nationalist sentiment behind its own vision of appropriate economic development and instrumental relations to nature. Yet when, figuratively speaking, Icelanders came face-toface with the Other embodied in Keiko, that common effort faltered. I am suggesting that what they glimpsed in Keiko was themselves, in all their frailties, reflected back in the mirror of nature. Their identification - that is, recognition of themselves within the tropes of home, family, and dependent relations with economically-powerful foreign nations-had to be simultaneously denied, disavowed so as not to challenge the hegemony of modernist thought.

Disavowing identification as 'mere' anthropomorphism is a cultural interpretation of what constitutes a rational, scientific mindset. While debate still revolves around the status of the animal as sentient agent in a social relationship between researcher and research subject, it is no longer possible to deny the role tropes and narratives play in constructing knowledge of the animal Other. The trope of rationality is of the same order as other stories of the relation between humans and whales. The tropes that Icelanders use to contain Keiko certainly 
manifest anxious narratives projected onto the silenced body of nature, a common enough phenomenon that many cultural analyses have explored in different contexts. But they do more than that. I argue that they express a hesitant broaching of a hitherto denied relationship-an actual, mutual social relation between human and non-human sentient nature —one that Icelanders, like the rest of us, will need to debate whether and how far to pursue.

\section{ACKNOWLEDGEMENTS}

I wish to gratefully acknowledge the financial support of the Social Science and Humanities Research Council of Canada, the Wenner Gren Foundation for Anthropological Research, and the Faculty of Social Sciences and Office of Research, University of Western Ontario. As well as providing research funding, the University of Iceland Research Centre, Westman Islands generously provided me with administrative support and accommodations during my visit in 1999. My thanks also to Gísli Pálsson, Helga Kristín Hallgrímsdóttir, Hjörleifur Jónsson, Pauline Greenhill, Regna Darnell, Andrew Lyons, Harriet Lyons, and the anonymous reviewers whose comments were much appreciated.

\section{ENDNOTES}

'Or should I say, "was returned"? What agency does the whale have at this or any other moment?

${ }^{2}$ In Iceland, public talks at the university are actually attended by the public, and in great numbers. The high participation of the public in civic debate and the life of ideas is one of the delights of being a researcher in that country.

${ }^{3}$ Vikverii is written by various, unnamed authors who assume the identity of Vikverji in their writing.

${ }^{4}$ porrablót is a midwinter festival at which traditional pickled, smoked, rotted, and dried foods are washed down with copious quantities of the national aquavit known colloquially as "Black Death." Satirical poetry recitations and singing folksongs round out the entertainment.

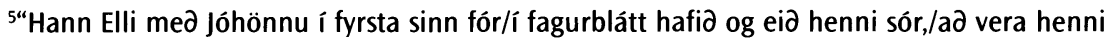

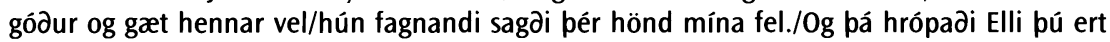
mín, pú ert mín./Ég fer aldrei uppúr, nei uppúr án pín."

${ }^{6} \mathrm{http}: / /$ stencilrevolution.com/photopost/showphoto.php?photo=281\&papass=\&sort. The

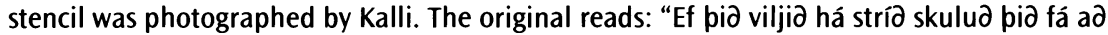

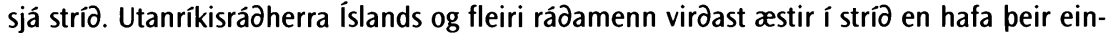

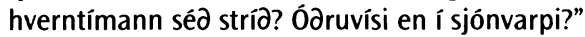

${ }^{7}$ The Danish parliament agreed in the 1960s to repatriate the manuscripts, and the first bundle was returned by ship to Iceland on the last day of winter, 21 April 1971, a day on which schools granted students a holiday.

${ }^{8}$ Persuading the Makah to resurrect this treaty right was an effective strategy by Japanese pro-whaling lobbyists to create complications for the United States' government's anti-whaling policies. Aboriginal whaling is now regulated as a separate category in the IWC. Aboriginal whaling had been ignored until the 1970s, but disputes over the Alaskan bowhead hunt prompted the Commission to codify a definition of Aboriginal whaling (Cherfas 
1988). Since that time the Japanese have tried both to have recognized another category called "small-type coastal whaling" (cf. Akimichi, et al. 1988) and to undermine the Aboriginal category on the basis of its discrimination against non-Aboriginals.

${ }^{9}$ http://www.pbs.org/wgbh/pages/frontline/shows/whales/interviews/mccaw1.html

${ }^{10} \mathrm{http}: / / \mathrm{www}$.hsus.org/ace/20158

${ }^{11} \mathrm{http} / / / \mathrm{www} .0$ canetwork.org/captivity/trainerletter.html

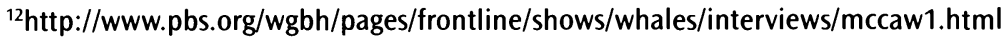

13“"The North Atlantic Killer Whale Project" undertook during 1986 and 1987 to review and assess knowledge about North Atlantic killer whales. Some of the resulting essays are published as a special issue of Rit Fiskideildar-Journal of the Marine Research Institute (volume $\mathrm{XI}, 1988$ ) and as a report to the International Whaling Commission in 1987 (SC/39/SM18).

\section{REFERENCES}

Appadurai, Arjun. 1996. Modernity at Large: Cultural Dimensions of Globalization. Minneapolis: University of Minnesota Press.

Árnason, Arnar, and Bob Simpson. 2003. "Refractions through Culture: The New Genomics in Iceland." Ethnos 68(4):533-553.

Brydon, Anne. 1990. "Icelandic Nationalism and the Whaling Issue." North Atlantic Studies 2(1/2):185-191.

1992. The Eye of the Guest: Icelandic Nationalist Discourse and the Whaling Issue. Ph.D. dissertation, Anthropology. McGill University, Montréal, Québec

. 1996. "Whale-sitings: Spatiality in Icelandic Nationalism." In G. Pálsson and P. Durrenberger, eds., Images of Contemporary Iceland: Everyday Lives and Global Contexts, 25-45. lowa City: University of lowa Press.

Bryld, Mette and Nina Lykke. 2000. Cosmodolphins: Feminist Cultural Studies of Technology, Animals and the Sacred. London: Zed Books.

Comaroff, Jean and John Comaroff. 1993. Modernity and Its Malcontents: Ritual and Power in Postcolonial Africa. Chicago: University of Chicago Press.

Davis, Susan G. 1997. Spectacular Nature: Corporate Culture and the Sea World Experience. Berkeley: University of California Press.

Desmond, Jane C. 1999. Staging Tourism: Bodies on Display from Waikiki to Sea World. Chicago and London: University of Chicago Press.

Drummond, Lee. 1995. American Dreamtime: A Cultural Analysis of Popular Movies and Their Implications for a Science of Humanity. Lanham, MD: Rowman and Littlefield Press.

Einarsson, Níels. 1993. "All Animals are Equal but Some are Cetaceans: Conservation and Culture Conflict." In Kay Milton, ed., Environmentalism: The View from Anthropology, 7384. London: Routledge.

. 1996. "A Sea of Images: Fishers, Whalers, and Environmentalists. In G. Pálsson and P. Durrenberger, eds., Images of Contemporary Iceland: Everyday Lives and Global Contexts; 46-59. lowa City: University of lowa Press.

Ferguson, James. 1999. Expectations of Modernity: Myths and Meanings of Urban Life on the Zambian Copperbelt. Berkeley: University of California Press.

Feuerbach, P.J.A.R. von. 1997. The Wild Child: The Unsolved Mystery of Kaspar Hauser. Jeffrey Moussaieff Masson, trans. Free Press. 
Freeman, Milton. 1990. "A Commentary on Political Issues with Regard to Contemporary Whaling." North Atlantic Studies 2(1/2):106-116.

Freeman, M. and U. Kreuter, eds. 1994. Elephants and Whales: Resources for Whom? Gordon $\&$ Breach.

Green, Alan. 1999. Animal Underworld: Inside America's Black Market for Rare and Exotic Species. New York: Public Affairs.

Hálfdanarson, Gudmundur. 2000. "pingvellir: An Icelandic Lieu de Mémoire." History and Memory 12(1):5-29.

Helgason, Jón Karl. 2003. Ferdalok. Reykjavík: Bjartur.

Ivy, Marilyn. 1995. Discourses of the Vanishing: Modernity, Phantasm, Japan. Chicago: University of Chicago Press.

Kalland, Arne. 1993. "Whale Politics and Green Legitimacy: A Critique of the Anti-Whaling Campaign." Anthropology Today 9(6):3-7.

Kalland, Arne and Brian Moeran. 1990. Endangered Culture: Japanese Whaling in Cultural Perspective. Copenhagen: Nordic Institute of Asian Studies Preprints No. 2.

Kitchen, Martin. 2001. Kaspar Hauser: Europe's Child. New York: Palgrave Macmillan.

Krech III, Shepard. 1999. The Ecological Indian: Myth and History. New York: W.W. Norton and $\mathrm{Co}$.

Lane, Harlan and Richard Pillard. 1976. The Wild Boy of Aveyron. Cambridge, Mass.: Harvard University Press.

Latour, Bruno. 1993. We Have Never Been Modern. Cambridge, Mass.: Harvard University Press.

McCrone, John. 1993. The Myth of Irrationality: The Science of the Mind from Plato to Star Trek. London: Macmillan.

Mintz, Sidney. 1985. Sweetness and Power: The Place of Sugar in Modern History. New York: Viking Penguin.

Mitchell, Timothy, ed. 2000. Questions of Modernity. Minneapolis: University of Minnesota Press.

Pálsson, Gísli and Paul Durrenberger, eds. 1996. Images of Contemporary Iceland: Everyday Lives and Global Contexts. lowa City: University of lowa Press.

Pálsson, Gísli and Kristín E. Hardardóttir. 2002. "For Whom the Cell Tolls: Debates about Biomedicine." Current Anthropology 43(2):271-301.

Papastergiadis, Nikos. 1993. Modernity as Exile: The Stranger in John Berger's Writings. Manchester: Manchester University Press.

Rapport, Nigel and Joanna Overing. 2000. Social and Cultural Anthropology: The Key Concepts. London: Routledge.

Renan, Ernest. 1990[1882]. "What Is a Nation?" In Homi K. Bhabha, ed., Nations and Narration, 8-22. London: Routledge.

Rofel, Lisa. 1999. Other Modernities: Gendered Yearnings in China after Socialism. Berkeley: University of California Press.

Rymer, Russ. 1994. Genie: A Scientific Tragedy. New York: HarperCollins.

Seremetakis, C. Nadia, ed. 1994. The Senses Still: Perception and Memory as Material Culture in Modernity. Chicago: University of Chicago Press.

Shattuck, Roger. 1994. The Forbidden Experiment: The Story of the Wild Boy of Aveyron. New York: Farrar Straus and Giroux.

Sigurdsson, Skúli. 2001. "Yin-yang Genetics, or the HSD deCode Controversy." New Genetics and Society 20(2):104-117. 
Singh, Joseph Amrito Lal, Robert Mowry Zingg, and P.J.A.R. von Feuerbach. 1966[c1942]. Wolf-children and Feral Man. Hamden, Conn.: Archon Books.

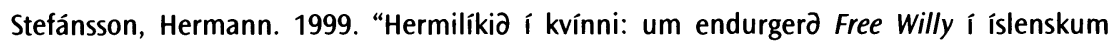
veruleika.” In Guani Elísson, ed., Heimur kvikmyndanna, 337-347. Reykjavík: Forlagid.

Viveiros de Castro, Eduardo. 2003. AND. After-dinner speech at Anthropology and Science, the 5th Decennial Conference of the Association of Social Anthropologists of Great Britain and Commonwealth, 14 July 2003. Published in Manchester Papers in Social Anthropology, 7, 2003.

Williams, Raymond. 1976. Keywords. London: Fontana.

Zizek, Slavoj. 1991. Looking Awry: An Introduction to Jacques Lacan through Popular Culture. Cambridge, Mass. and London: MIT Press. 